\title{
Penggunaan Biopestisida Nabati Dari Bahan Dasar TOGA Untuk Pengendalian Hama Rayap Pada Pembibitan Pala Dan Cengkeh Milik Kelompok Tani Spirit Di Desa Liliboi
}

\author{
Fransina Latumahina, Gun Mardiatmoko, Marthina Tjoa \\ Fakultas Pertanian, Universitas Pattimura, Ambon, Indonesia
}

\begin{abstract}
ABSTRAK
Rayap adalah serangga sosial yang berasal dari ordo Isoptera dapat menimbulkan kerugian ekonomi yang cukup tinggi, dimana rayap akan menyerang bagian batang hingga akar tanaman akibatnya daun tanaman akan menguning, batang akan membengkak dan akar tanaman terputus. Serangan rayap yang terjadi secara terus menerus akan semakin sulit dibasmi apabila tidak mendapat perhatian yang serius oleh petani. Petani Desa Liliboi mengalami kesulitan dalam budidaya tanaman pala dan cengkeh karena setiap tahun selalu diserang oleh rayap dengan intensitas kerusakan sedang hingga tinggi dengan luas serangan lebih dari $50 \%$. Kondisi ini sangat berdampak buruk terhadap kualitas maupun kuantitas tanaman yang dibudidayakan didalam areal hutan kemasyarakatan Desa Liliboi. Warga kehilangan tanaman Pala dan Cengkeh bahkan terjadi penurunan pendapatan masyarakat dari pengelolaan hutan rakyat milik petani hutan. Pengendalian hama rayap umumnya dilakukan oleh petani setempat dengan menggunakan bahan kimia diantaranya Furadan, Sutrin 100 EC dan Bantrek 480 EC yang harganya sangat mahal dan sulit terjangkau oleh kelompok tani, akibatnya mereka selalu merugi tiap tahunnya. Untuk itu perlu dicari solusi yang tepat dalam menangani persoalan yang dihadapi oleh kelompok tani Desa Liliboi. Salah satu solusi yang dapat ditawarkan kepada petani yakni penggunaan biopestisida nabati dari Tanaman Obat keluarga (TOGA) yang mudah dan murah didapat untuk memberantas serangan rayap yakni Sereh, Daun Pepaya dan Daun Sirsak. Biopestisida nabati memiliki keuntungan antara lain mudah terurai di alam sehingga tidak mencemari lingkungan serta relatif aman bagi manusia dan hewan peliharaan karena residunya mudah hilang. Penggunaan biopstisid nabati dalam dalam jumlah (dosis) yang kecil atau rendah, mudah diperoleh di alam, dan cara pembuatannya relatif mudah dan secara sosial ekonomi penggunaannya menguntungkan bagi petani kecil. Pembuatan biopestisida secara sederhana berorientasi kepada penerapan usaha tani berinput rendah, sehingga target yang akan dicapai dari kegiatan PKM yakni meningkatnya pengetahuan dan ketrampilan kelompok tani hutan melalui perbaikan sistem budidaya dan pemeliharaan tanaman pala dan cengkeh hutan, peningkatan kemampuan petani dalam mendiagnosa gejala serangan hama rayap pada pala dan cengkeh serta kemampuan petani meracik obat pembasmi hama rayap secara masal dari bahan TOGA untuk meningkatan produktivitas tanaman sehingga pada akhirnya akan meningkatkan kesejehteraan ekonomi masyarakat petani. Kegiatan yang akan dilaksanakan yakni penguatan kapasitas kelompok tani melalui kegiatan penyuluhan tentang budidaya tanaman pala dan cengkeh, pengenalan gejala dan tanda serangan rayap, peracikan bahan obat pembasmi hama rayap dan pembuatan biopestisida nabati dari tanama obat keluarga (TOGA) yakni Daun Sereh, Daun Pepaya dan Daun Sirsak dalam bentuk larutan. Oleh sebab itu dilaksanakan kegiatan pengabdian masyarakat untuk mencari solusi yang dihadapi masyarakat yang dilakukan dengan 2 cara yaitu: (1) presentasi materi biopestisida, budidaya pala-cengkeh yang diikuti dengan diskusi dan (2) demo pembuatan biopestisida dari bahan tanaman obat keluarga daun pepaya, sereh dan daun sirsak. Hasil diskusi yang berlangsung selama kegiatan presentasi terungkap banyaknya pertanyaan dari peserta yang belum banyak memahami budidaya pala dan cengkeh serta penggunaan biopestisida guna mendukung pertanian organik, juga tentang pemahaman mengenai cara perawatan pala-cengkeh, pembuatan biopestisida nabati dari tanaman obat keluarga yang bahan-bahannya mudah didapat didesanya. Demo pembuatan biopestisida berjalan dengan lancar dimana peserta juga terlibat aktfif dalam demo tersebut sehingga diharapkan nanti mereka bisa membuat sendiri biopestisida untuk memenuhi kebutuhan kelompok tani.
\end{abstract}

Kata Kunci : Biopestisida, Pemberdayaan Masyarakat, Tanam Obat Keluarga 


\section{PENDAHULUAN}

Negeri Lilibooi terletak di pinggiran Kota Ambon termasuk dalam wilayah Kabupaten Maluku Tengah, namun berada satu daratan dengan wilayah Kota Ambon, memiliki jumlah penduduk sebanyak 1.982 jiwa, terdiri dari laki-laki sebanyak 997 jiwa dan perempuan sebanyak 985 jiwa dengan 518 Kepala Keluarga (KK). Penduduk desa Liliboi bekerja sebagai nelayan, PNS dan petani dimana petani memanfaatkan areal kebun dan dusun untuk bercocok tanam. Petani hutan yang tergabung dalam kelompok tani hutan rakyat umumnya menanam Pohon Pala (Myristica fragran) dan Cengkeh (Zyzgium aromaticum) untuk tujuan komersil. Dalam dasawarsa terakhir pasca konflik sosial di Maluku, petani Desa Liliboi mulai berkonsentrasi sebagai petani hutan dengan melakukan budidaya tanaman hutan dan perkebunan untuk tujuan komersil antara lain Pohon Pala dan Cengkeh untuk dijual ketika telah masak tebang. Pada awal penamanan di tahun 2015 tanaman pala dan cengkeh tidak mengalami kendala dengan kehadiran hama maupun penyakit, namun dalam dua tahun tahun terakhir petani setempat mengalami penurunan hasil produksi sekitar $30 \%$ akibat akibat serangan hama rayap yang terjadi secara terus menerus sepanjang tahun. Serangan rayap sering terjadi pada Bulan Juni - Agustus sepanjang tahun sejak tahun 2018 pada saat intensitas curah hujan meningkat di wilayah Kota Ambon, akibatnya terjadi gagal panen dan penurunan produksi. Serangan rayap umumnya diatasi oleh petani dengan pemberian insektisida Furadan, Sutrin 100 EC dan Bantrek 480 EC yang harganya mencapai Rp. $150.000 /$ botolnya. Kondisi ini sangat memberatkan petani ditambah lagi dengan minimnya pengetahuan petani tentang pengendalian hama rayap, akibatnya pada tahun 2018 - 2019 tingkat penjualan bibit Pala dan Cengkeh di Desa Mitra mengalami penurunan. Tiap tahunnya kelompok tani memperoleh penghasilan dari hasil penjualan anakan pala dan cengkeh sekitar Rp. 20.000.000/tahun, namun akibat serangan hama rayap petani hanya mendapat omzet bersih/tahun sekitar Rp. 9.000.000/tahun. Tanaman obat keluarga ( TOGA) dapat ditemukan berlimpah pada halaman rumah penduduk dan dalam kawasan hutan rakyat milik desa, namun selama ini hanya dimanfaatkan sebagi obat tradisonal bagi warga yang sakit, namun tidak pernah dimanfaatkan sebagai biopestisda nabati pengendali hama dan penyakit tanaman. Oleh karena itu, melalui kegiatan ini, diharapkan TOGA dapat dimanfaatkan secara optimal untuk pengendalian hama dan penyakit.

Seiring dengan keinginan dan kesungguhan sebagian besar masyarakat di dunia untuk kembali ke alam atau back to nature maka dewasa ini telah mengemuka istilah pertanian organik. Secara sederhana pertanian organik diartikan sebagai teknik budidaya dan pengusahaan pertanian dengan mengandalkan input dan sarana produksi bahan alami (organik) tanpa memakai kimia sintetis. Dikembangkannya pertanian organik di dunia bertujuan untuk menyediakan berbagai produk pertanian. Produk pertanian organik tersebut dikhususkan untuk ketersediaan bahan pangan yang aman dan sehat bagi bagi produsen (petani) maupun konsumen dan teristimewa tidak merusak lingkungan hidup. Untuk menjamin bahwa produk itu berasal dari pertanian organik maka petani penghasil atau produsennya perlu memproduksi saprodi pertanian organik yang digunakan dalam proses budidaya organic serta mempunyai sertifikat organik. Sertifikat ini terkait dengan adanya label organic pada hasil pertanian organik. Label tersebut mengindikasikan bahwa konsumen mendapatkan kepastian bahwa produk pertanian yang dibeli dan dikonsumsi itu dengan cara pertanian organik yang tidak memakai bahan kimia (FAO, 1999). 
Beberapa alasan mengapa masyarakat beralih ke pertanian organik yaitu karena pada hasil pertanian konvensional dengan pupuk anorganik (kimia) telah menimbulkan penyakit asma. kanker, ADHD, asma dan berbagai penyakit lainnya; Pertanian organik mempromosikan keragaman hayati dengan mendorong ekosistem penuh pada pertanian; Adanya pengurangan ketergantungan pada sumber daya tak terbarukan. Hasil pertanian organik ternyata mengandung kadar antioksidan tinggi dibandingkan non-organik. Selain itu, pada pertanian organik itu mempunyai wawasan ke depan yang terlihat panjang, dengan mempertahankan kualitas tanah yang baik. Kualitas tanah didapat melalui penggunaan rotasi tanaman dan musuh alami sebagai sarana pengendali masalah budidaya yang di dikombinasikan dengan penggunaan berbagai teknik ilmiah modern. Untuk mendukung pertanian organik antara lain perlu dibuat biopestisida dan pupuk organik. Biopestida merupakan jenis pestisida tertentu yang berasal dari bahan alami seperti hewan, tumbuhan, bakteri, dan mineral tertentu. Misalnya, minyak kanola dan soda kue memiliki aplikasi pestisida dan dianggap sebagai biopestisida (EPA, 2017). Dengan demikian jika berubah menuju ke pertanian organik setidaknya masyarakat telah sadar akan pentingnya kesehatan. Kesehatan masyarakat meningkat akan meningkatkan energi dan fungsi tubuh akan meningkat dan kehidupan masyarakat akan terasa lebih baik. Jadi, kesehatan merupakan modal yang tidak dapat tergantikan dalam kehidupan di dunia. Untuk sehat itu perlu biaya yang lebih besar sebab dengan mengkonsumsi produk pertanian organik tersebut akan dikenai harga premium. Produk tersebut perlu bersertifikat organik dimana secara umum lebih mahal jika dibanding dengan pertanian konvensional karena beberapa alasan seperti penawaran pangan organik lebih terbatas dibandingkan dengan permintaan; biaya produksi pangan organik relatif lebih tinggi karena membutuhkan imput tenaga per unit yang lebih besar, Penanganan pasca-panen berbagai hasil pangan organik jumlahnya relatif kecil pada biaya yang lebih tinggi terutama pada bagian angkutan dan prosesing; Rantai distribusi dan pemasaran untuk produk pangan organik relatif tidak efisien dan beaya tinggi karena volumenya yang relatiff kecil (FAO, 2000). Situasi kelompok tani Spirit Desa Liliboi dapat dilihat pada gambar $1-2$ dibawah ini. 

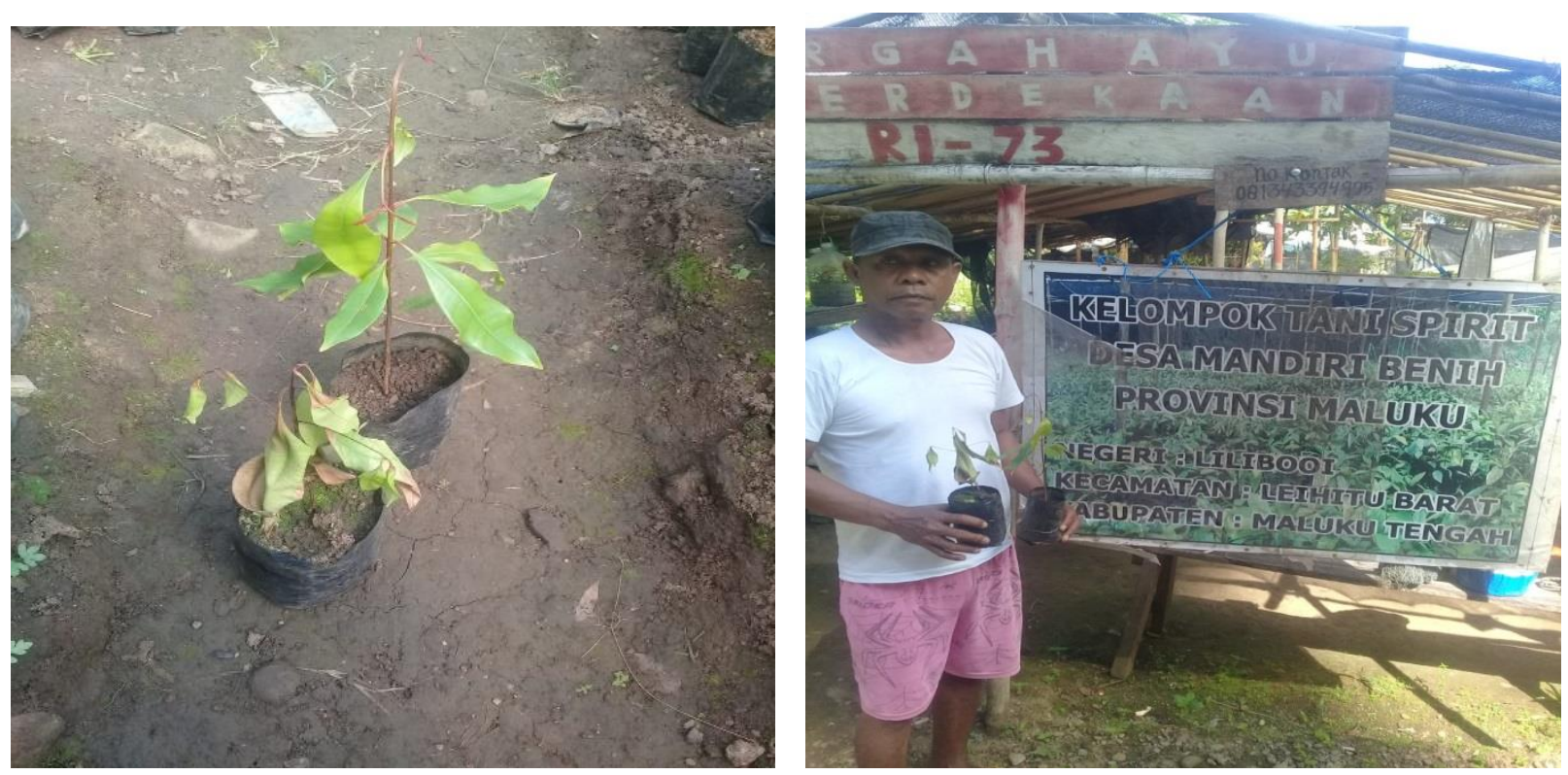

Gambar 1. Kondisi Anakan Pala dan Cengkeh Yang Mengalami Serangan Rayap

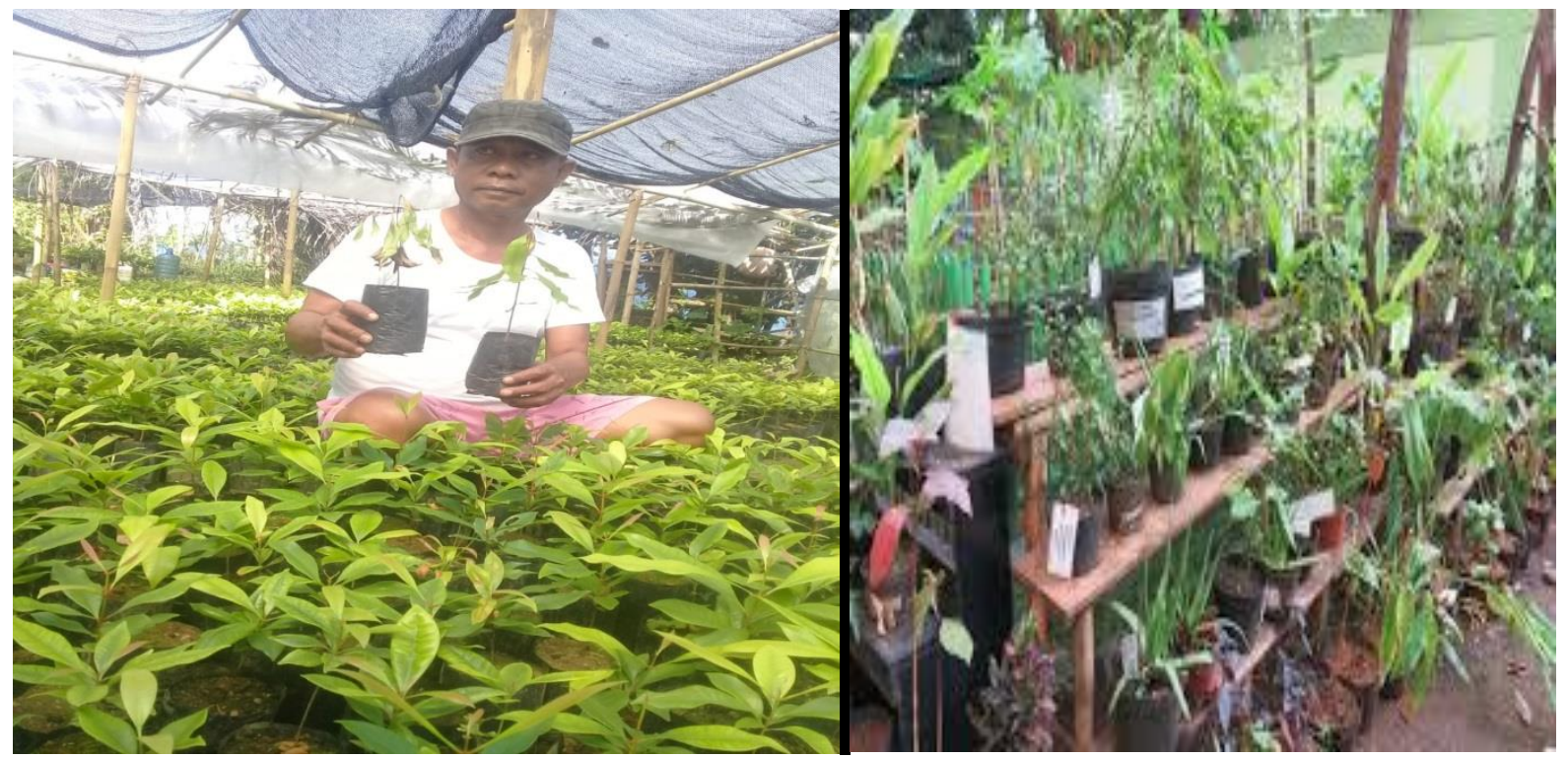

Gambar 2. Pembibitan Pala dan TOGA Milik Kelompok Tani

Kondisi ini apabila dibiarkan berlarut - larut maka kelompok tani akan mengalami kerugian yang besar, dan suatu saat aktivitas kelompok tani akan terhenti dan tidak lagi berproduksi, padahal peluang dari usaha budidaya anakan pala dan cengkeh di Maluku memiliki prospek pasaran yang sangat besar. Desa Liliboi memiliki kelompok tani hutan yang sehari - hari bekerja sebagai pembudidaya anakan pala dan cengkeh. Tiap kelompok tani umumnya mengusahakan 200 - 500 anakan pala dan cengkeh dalam sebulan, dengan total omzet Rp. 2.000.000/bulannya. Data yang diperoleh dari tiap kelompok tani, diketahui bahwa pada pada Tahun 2017 - 2019, mengalami kegagalan panen karena banyaknya anakan yang 
mati akibat serangan rayap tanah (Cryptotermes spp). Akibat serangan rayap tanah, terjadi perubahan warna daun, daun menggulung, mengering dan akhirnya mati hanya dalam waktu 2 minggu. Terhadap situasi ini, maka dapat diidentifikasi beberapa permasalahan yang terjadi pada kelompok tani Hutan Desa Liliboi yakni :

1. Rendahnya pengetahuan petani tentang budidaya pala dan cengkeh secara baik dan benar

2. Minimnya pengetahuan dan informasi yang dimiliki oleh petani tentang bagaimana mencegah serangan hama dan penyakit pada anakan pala dan cengkeh

3. Tingginya intensitas curah hujan yang terjadi di Kota Ambon pada saat musim penghujan

4. Mahalnya obat pembasmi hama rayap yang dijual dipasaran, sehingga sulit dijangkau oleh petani

5. Minimnya kegiatan penyuluhan ataupun pendampingan dari instansi teknis terkait dalam melakukan pendampingan kepada kelompok tani, sehingga petani hanya bekerja dengan kemampuan yang terbatas, hal ini merupakan permasalahan bagi kelompok mitra untuk berusaha dan berkembang.

6. Petani tidak memiliki pengetahuan tentang pembuatan obat pembasmi hama rayap yang dapat dibuat dari bahan alami.

Serangan rayap terjadi bukan saja pada anakan pala dan cengkeh namun juga tingkat tiang dan pohon, seperti pada gambar 3 dibawah ini. Pada saat terjadi serangan rayap, batang pohon akan terpecah dan daun mongering dan akan mati apabila tidak diobati. Petani umumnya akan menggunakan bahan kimia untuk membunuh rayap yang menyerang (Gambar 3)

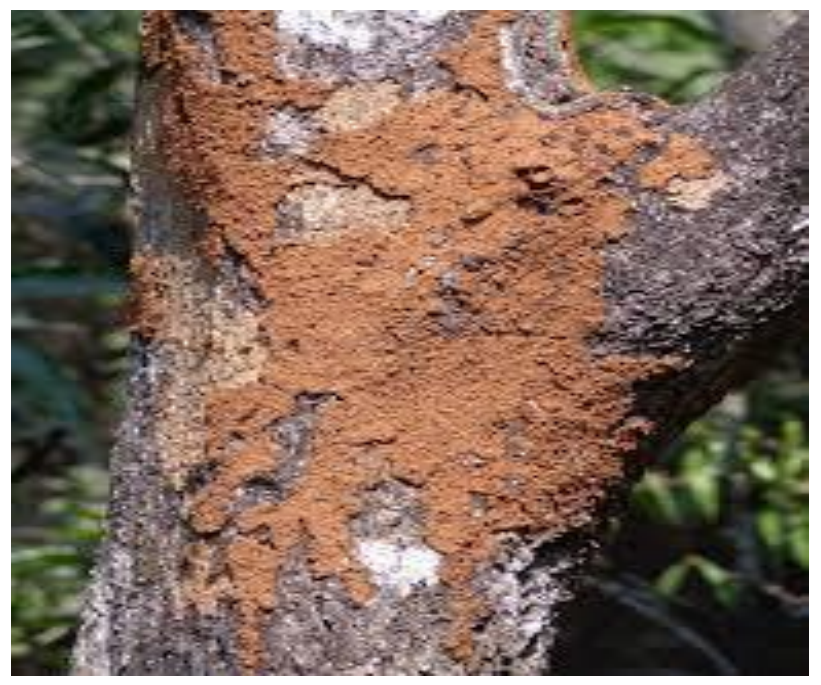

Gambar 3. Serangan Hama Rayap pada Pohon Pala 


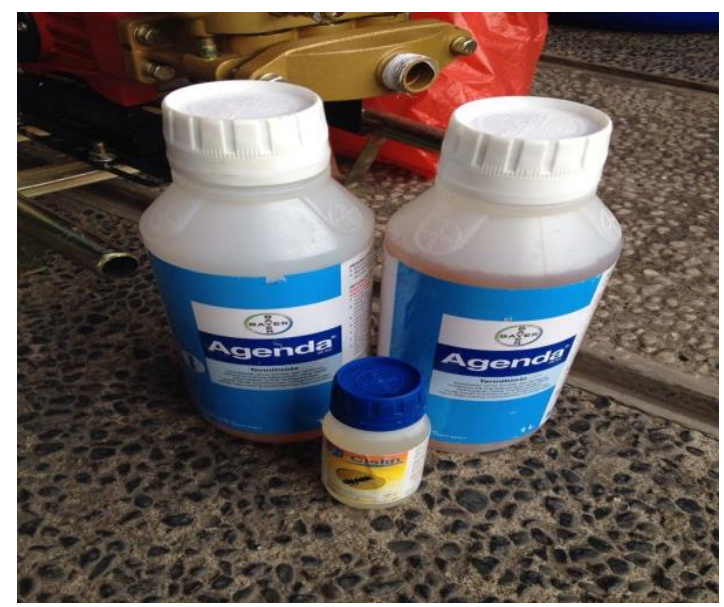

Gambar 4. Pembasmi Rayap yang Selalu Digunakan Petani

Berdasarkan permasalahan yang dihadapi oleh kelompok mitra maka kegiatan pengabdian kepada masyarakat dapat membantu kelompok tani hutan Desa Liliboi untuk mengatasi masalah serangan rayap sehingga dengan sendirinya akan mempengaruhi kesejahteraan petani.

\section{METODE PELAKSANAAN}

Program sosialisasi dan pelatihan pembuatan biopestisida dan pupuk organik padat dan cair ini dilaksanakan bersama Kelompok Tani Spirit, Desa Liliboi, Kabupaten Maluku Tengah. Desa ini terletak di P. Ambon dan jaraknya sekitar $17 \mathrm{~km}$ dari Kota Ambon. Kelompok tani di Desa Liliboy yang eksis dan berpengaruh besar terhadap pembangunan desanya yaitu Kelompok Tani Spirit. Kelompok tani ini sudah cukup lama menjadi binaan Dinas Pertanian Provinsi Maluku dan semakin berkembang pesat setelah menjadi tempat kegiatan pengembangan pala-cengkeh dalam program Spice Up the Deal (SUD) yang merupakan hasil kolaborasi Mercy Corps dengan Dewan Rempah Maluku. Dengan kegiatan tersebut Kelompok Tani Spirit telah berhasil memproduksi bibit pala-cengkeh bersertifikat dan menjualnya ke pasaran bahkan telah mampu menggerakkan seluruh masyarakat di desanya untuk dapat melakukan pembibitan pala-cengkeh dan menjualnya. Tidak mengherankan jika di hampir semua halaman rumah terdapat stok bibit pala-cengkeh yang siap dijual. Produksi pala-cengkeh dan tanaman semusimnya sama sekali tidak menggunakan bahan-bahan kimia. Metode yang dilaksanakan yaitu:

1) Pencarian permasalahan pertanian organik di Desa Liliboi

Pada awalnya Tim Unpatti mengunjungi Aparat Desa Liliboi dan Kelompok Tani Spirit di tempat kerjanya di areal persemaian pala-cengkeh dan mencari masukan berbagai permasalahan yang ada dan ditemukan masalah adanya serangan hama rayap, ulat daun yang menyerang bibit pala-cengkeh di persemaian dan belum banyak mengetahui pembuatan biopestida dan pembuatan pupuk organik padat dan cair. Selain itu ada kelesuan dari Kelompok Tani akibat kesulitan pemasaran dan belum bisa menikmati harga premium yang seharusnya didapat. Jadi ini masalah sangat 
serius yang perlu dicari solusi mengingat Desa Liliboi telah dicanangkan sebagai Desa Pertanian Organik.

2) Berdasarkan permasalahan tersebut Tim Unpatti segera menyusun Usulan Program Kemitraan (PKM) berjudul: Pembuatan Biopestisida Nabati Berbahan Dasar Tanaman Obat Keluarga untuk Mengatasi Serangan Rayap pada Pembibitan Pala dan Cengkeh di Desa Liliboi, Provinsi Maluku ke Dikti. Setelah proposal diterima dan tersedia dananya maka Tim Unpatti segera melaksanakan kegiatan pengabdian masyarakat di lapangan.

3) Pelaksanaan pengabdian masyarakat di Desa Liliboi dilakukan dengan 2 cara yaitu: (1) presentasi materi biopestisida, pembuatan pupuk organik, cara budidaya palacengkeh yang diikuti dengan diskusi dengan peserta dan (2) demo pembuatan biopestisida dan pupuk organik. Peserta juga diberikan toolkit berisi ATK dan brosur yang berhubungan dengan pertanian organik.

Mengingat pelaksanaan pengabdian masyarakat di Desa Liliboi pada saat pandemi Covid-19 maka serluruh proses pelaksanaan mulai dari awal sampai dengan akhir dilakukan dengan menjalankan protokol kesehatan seperti yang diwajibkan oleh Pemerintah (Gambar 1)
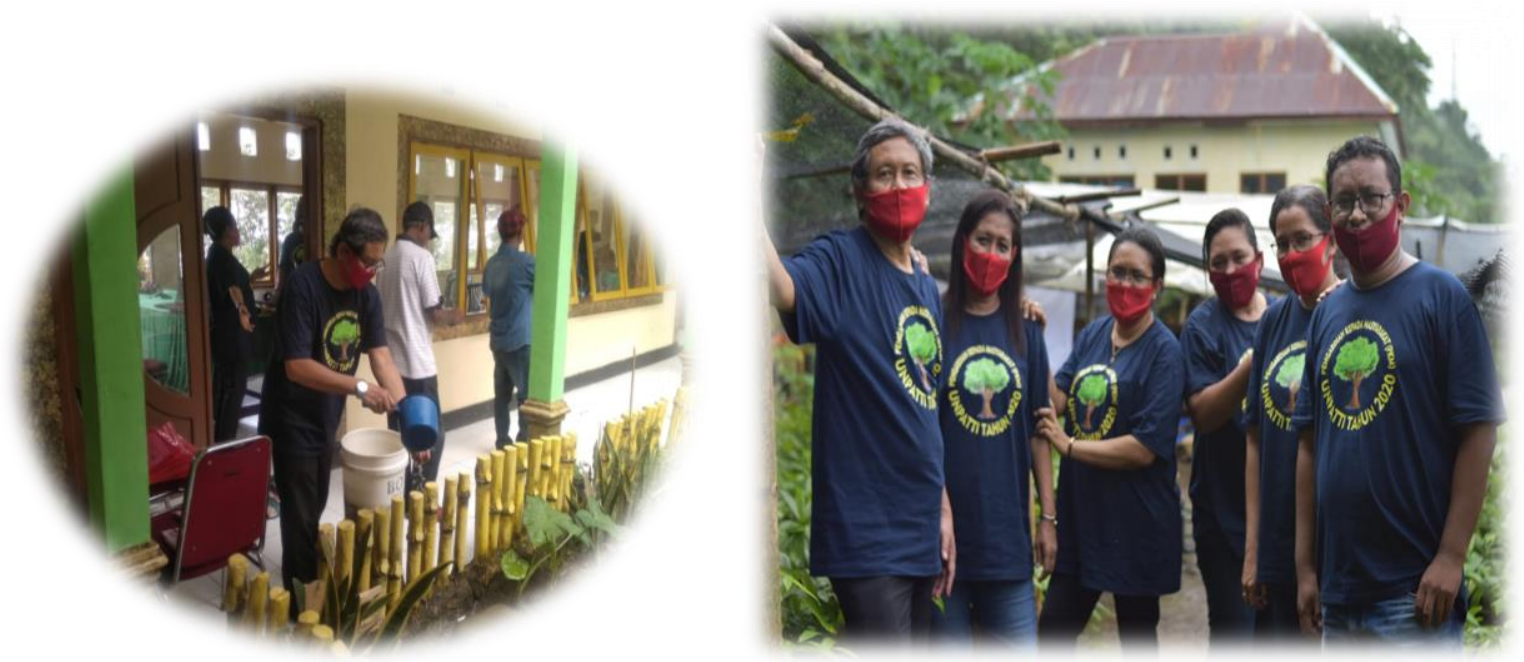

Gambar 5. Tim Pengabdian masyarakat Unpatti menjalankan protokol kesehatan

\section{HASIL DAN PEMBAHASAN}

\section{Presentasi Materi}

Presentasi materi materi terbagi atas tiga dan diikuti dengan diskusi dengan peserta ;

1) Presentasi pertama adalah cara budidaya pala-cengkeh dengan topik cara perawatan tanaman cengkeh agar cepat berbuah dan upaya mengatasi tanaman pala yang berbunga namun tidak bisa berbuah. Presentasi ini melalui penayangan 
materi dengan powerpoint yang didalam slide terdapat video yang berasal dari youtube. Selanjutnya dilakukan diskusi dengan peserta.

2) Presentasi kedua yaitu penyampaian materi tentang pentingnya biopestisida dan cara pembuatannya. Setelah selesai presentasi tersebut dilanjutkan juga dengan diskusi.

Pada kegiatan ini baik saat presentasi maupun tanya jawab dengan peserta dapat berjalan dengan lancar. Dari isi diskusi yang berlangsung selama kegiatan presentasi terungkap banyaknya pertanyaan dari peserta yang belum banyak memahami budidaya pala-cengkeh dengan penggunaan biopestisida nabati dari daun Sirsak, Pepaya dan Sereh. Suasana presentasi disajikan pada Gambar 6.
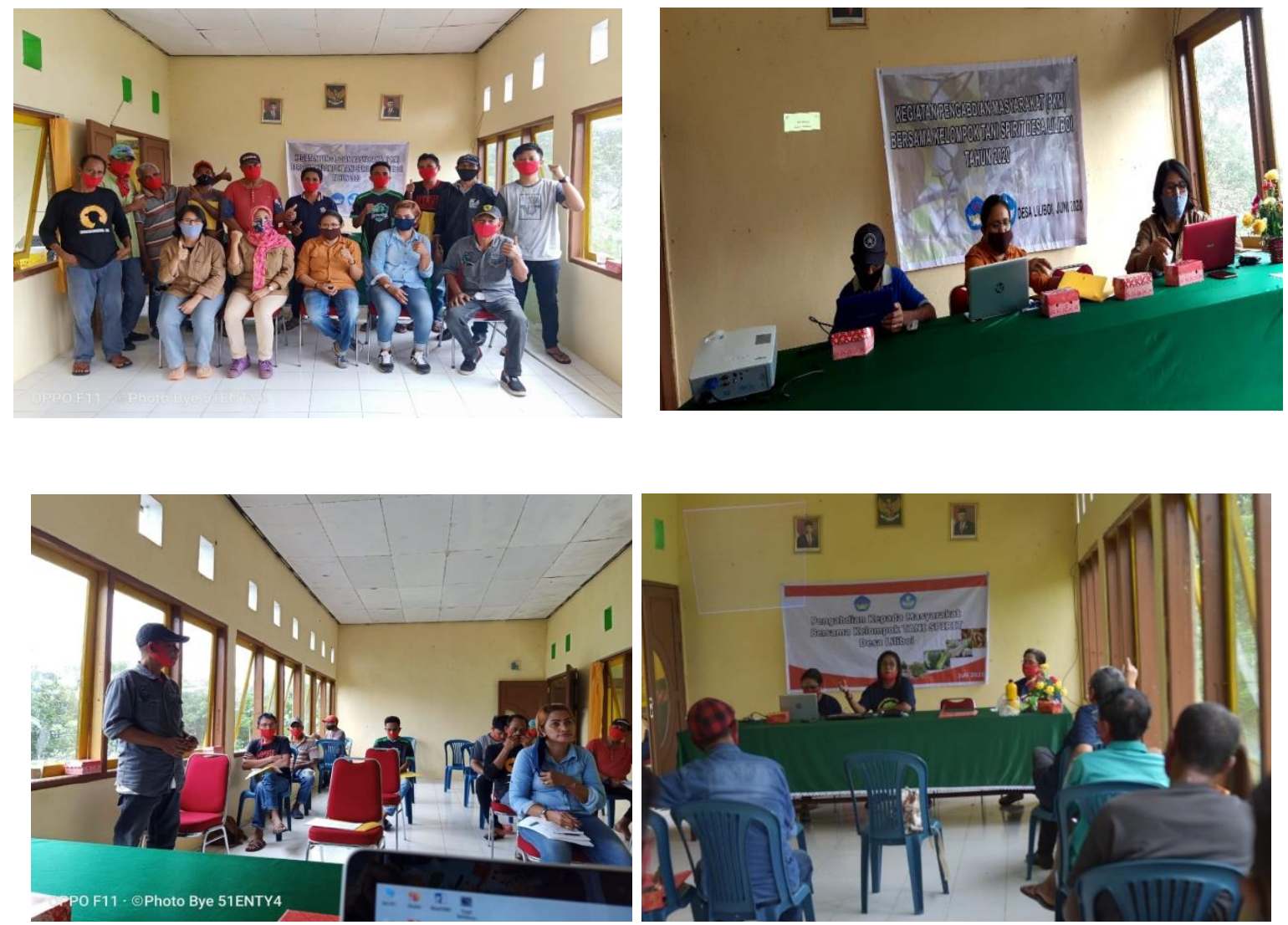

Gambar 6. Penguatan Kapasitas Petani Pala dan cengkeh

Bahan aktif pestisida nabati adalah produk alam yang berasal dari tanaman yang mempunyai kelompok metabolit sekunder yang mengandung beribu-ribu senyawa bioaktif seperti alkaloid, terpenoid, fenolik, dan zat - zat kimia sekunder lainnya. Senyawa bioaktif tersebut apabila diaplikasikan ke tanaman yang terinfeksi OPT (Organisme Penganggu Tanaman), tidak berpengaruh terhadap fotosintesis pertumbuhan ataupun aspek fisiologis tanaman lainnya, namun berpengaruh terhadap sistem saraf otot, keseimbangan hormon, reproduksi, perilaku berupa penarik, anti makan dan sistem pernafasan OPT. Di Indonesia sebenarnya sangat banyak jenis tumbuhan penghasil pestisida nabati, diperkirakan sekitar 
2400 jenis tanaman yang termasuk ke dalam 235 famili . Pembuatan biopestisida nabati yang diajarkan kepada petani dilakukan dengan langkah - langkah sebagai berikut :

1. Siapkan daun sirsak, daun sereh dan daun pepaya yang telah dicuci bersih kemudian di keringkan

2. Daun sirsak, daun sereh dan daun pepaya diiris halus kemudian ditimbang, untuk daun sirsak dan daun sereh sebanyak 1000 gram, sedangkan daun pepaya 1.500 gram kemudian ditumbuh hingga halus secara terpisah

3. Masukkan daun sirsak dan daun sereh pada toples tambahkan dengan air sebanyak 10 liter, sedangkan daun pepaya dimasukkan pada toples dan ditambahkan air sebanyak 5 liter ditutup dan dibiarkan selama 24 jam dan keesokan harinya saring rendaman menggunakan kain halus.

4. Tiap 1 liter larutan yang sudah disaring kemudian diencerkan dengan 10 liter air kemudian tambahkan 1 sendok teh sabun colek, dan di kocok atau diaduk.

5. Semprotkan larutan pada tanaman yang terkena serangan hama maupun penyakit.

Demo Pembuatan Biopestisida Nabati dari bahan Dasar Tanaman Obat keluarga

1) Demo pertama yang dilakukan adalah pembuatan biopestisida nabati. Pada kegiatan ini Tim Unpatti telah menyiapkan semua bahan dan alat untuk pembuatan biopestisida. Pada aktivitas ini baik Tim Unpatti maupun peserta semuanya aktif dalam pembuatan biopestisida dengan harapan terciptanya kondisi learning by doing. Dengan demikian setelah pelatihan selesai peserta bisa menyiapkan bahan-bahan biopestisida serta membuatnya sendiri.

2) Setelah pelatihan selesai maka peserta diharapkan bisa menyiapkan bahan-bahan pembuatan pupuk organik serta membuatnya sendiri.

Dengan telah selesainya kegiatan ke dua pelatihan tersebut maka pada persemaian bibit dari Kelompok Tani Spirit dilakukan observasi bibit pala-cengkeh yang terserang hama rayap dan terserang ulat daun lalu dilakukan penyemprotan biopestisidanya. Suasana demo pembuatan biopestisida dan pupuk organik disajikan pada Gambar 7. 

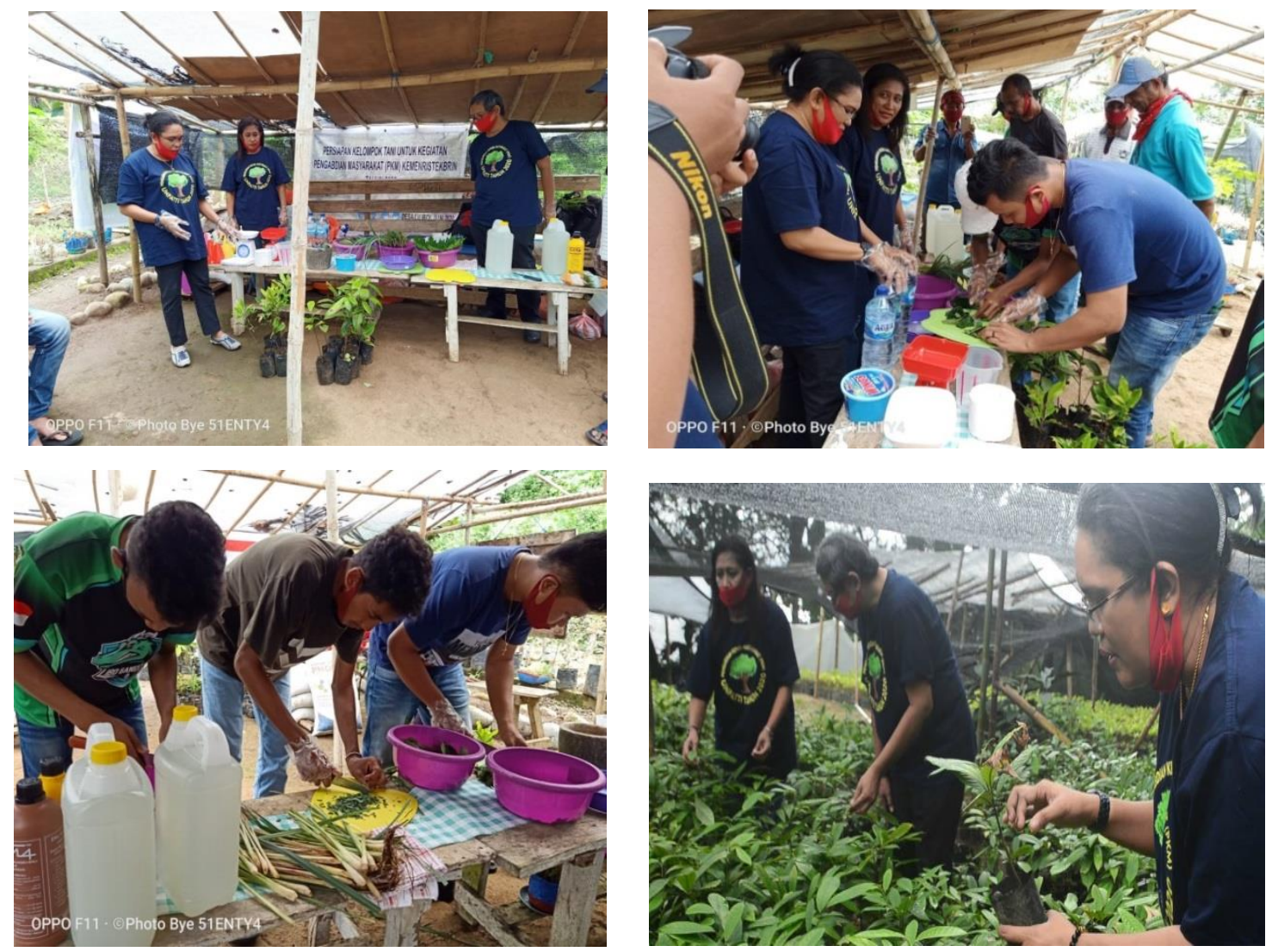

Gambar 7. Suasana demo pembuatan biopestisida nabati dari bahan dasar TOGA

\section{KESIMPULAN DAN SARAN}

Kegiatan pelatihan pembuatan biopestida nabati dari bahan dasar tanaman obat keluarga di Desa Liliboi berjalan dengan baik dan lancar. Kelompok Petani Spirit dapat memperoleh wawasan yang lebih luas dalam pembuatan biopestisida nabati sehingga dapat diharapkan mereka lebih percaya diri terhadap status desanya sebagai Desa Pertanian Organik.

Dari hasil kegiatan pelatihan dapat disarankan bahwa perlu upaya pendampingan dan pembinaan kepada para peserta agar penerapan hasil pelatihan dapat dievaluasi dan untuk memantau perkembangan aplikasi program sehingga dapat mendukung terciptanya pertanian organik yang mampu menyejahterakan masyarakat Desa Liliboi tersebut. Selain itu perlu ada kegiatan lanjutan yaitu terutama untuk membantu terciptanya pemasaran dari produk pertanian organik sehingga masyarakat dapat menikmati harga premium dari hasil pertanian organiknya. 


\section{DAFTAR PUSTAKA}

EPA. 2017. What are Biopesticides? https://www.epa.gov/ingredients-used-pesticideproducts/what-are-biopesticides (diakses 9 Juli 2020).

FAO, 1999. Organic Culture. http://www.fao.org/organicag/oa-faq/oa-faq1/en/ (diakses 8 Juni 2014)

FAO, 2000. Why is organic food more expensive than conventional food? http://www.fao.org/organicag/oa-faq/oa-faq5/en/ (diakases 8 Juni 2014)

Permentan No.2. 2006. Peraturan Menteri Pertanian No. 02/Pert/HK.060/2/2006 tetang Pupuk Organik dan Pembenah Tanah. Tanggal 10 Februari 2005. 